Tiruneh, D.T. (2021). Empirical Evidence of the Suitability of IFRS for Banking Sector in Sub-Saharan African Countries. Copernican Journal of Finance \& Accounting, 10(2), 63-79. http://dx.doi. org/10.12775/CJFA.2021.008

\author{
Dawit Tadesse Tiruneh* \\ GAMBY Medical and Business College
}

\title{
EMPIRICAL EVIDENCE OF THE SUITABILITY OF IFRS FOR BANKING SECTOR IN SUB-SAHARAN AFRICAN COUNTRIES
}

Keywords: IFRS, suitability, Sub-Saharan Africa region, Africa, Ethiopia, Ethiopian banking sector.

J E L Classification: G21, M10, M41, M42, M48, M49.

Abstract: The reason for this investigation was to survey the appropriateness of International Financial Reporting Standards (IFRS) in sub-Saharan African nations banking sector like Ethiopia. The following research endeavors to acquire experiences into the benefits and detriments of IFRS execution in Ethiopian Banking sector depending on the view of banks financial directors, scholastics in accounting and external auditor. Examination is insightful of online overview, which intends to clarify the appropriateness of IFRS as opposed to depict a population. Along these lines, representativeness of the example to the population was not the objective of the examination; it endeavors rather to guarantee legitimacy of the information by applying purposive testing (Oppenheim, 1992). In such manner an aggregate of 30 surveys were conveyed to banks financial supervisors, scholastics and external auditors who have rich information and involvement with IFRS execution in financial sector in Ethiopia. Of the 26 answers (87 percent), 26 finished polls were broke down.

The outcomes recommend that IFRS execution is appropriate for the banking sector of Ethiopia regardless of whether banks are causing extra significant expenses to carry

Date of submission: March 24, 2021; date of acceptance: May 2,2021.

* Contact information: dawittadesse9053@yahoo.com, GAMBY Medical and Business College and Addis Ababa University School of Commerce, Ethiopia and Managing Partner of Lead Plus consulting, Ethiopia, phone: 251911109648; ORCID ID: https://orcid.org/0000-0001-5885-6539. 
out the standards. The selection of IFRS gives numerous benefits to the financial sector climate without logical inconsistency with Ethiopian financial laws and corporate duty. The advantages that the financial sector in Ethiopia will get from IFRS execution pertinently and dependably addresses the financial reports more than its execution cost.

\section{INTRODUCTION}

Accounting data is the main wellspring of data for interior and outer clients (Gordon, 2008; Jermakowicz \& Gornik-Tomaszewski, 2006; Callao, Jarne \& Laínez, 2007; Rahman, Lei \& Courtenay, 2014; Houqe \& Monem, 2016; Tahat, Dunne, Fifield \& Power, 2016; Mohammadi \& Mardini, 2016; Mardini \& Tahat, 2017). It gives subjective and quantitative information about an element and its financial circumstance that guides financial data clients in their dynamic (Benjamin \& Stanga, 1977). To meet clients' dynamic necessities, financial data should be applicable and dependable.

The standard setting measure traces all the way back to 1973 with the International Accounting Standards Committee (IASC, 1989) (Christian \& Kohlmeyer III, 2009). The IASC built up a bunch of standards that were perceived all through the world, however in 2001 with the formation of the International Accounting Standards Board (IASB, 2010) the interaction sped up (Christian \& Kohlmeyer III, 2009). The global standard setting measure turned into a work to build up a bunch of basic norms on the grounds that the created countries understood the significance of equivalence, and straightforwardness for financial backers, controllers, enormous organizations and reviewing firms around the world (Christian \& Kohlmeyer III, 2009).

In the course of recent many years, the financial and financial climate of Ethiopia has changed essentially (ADB, 2020). As the consequence of this financial development, the quantity of banks is filling in Ethiopia. Right now, it arrived at 18, of which 16 are private and 2 are state-claimed in 2017/18 (Mesele, 2019).

Truth be told Ethiopia has begun to utilize IFRS in financial revealing without precedent for 2002/03. The primary associations that utilized the term IFRS without precedent for their yearly report in Ethiopia are government possessed elements like Commercial Bank of Ethiopia, Construction and Business Bank, Ethiopian Insurance Corporation and Ethiopian Airline. Right now there was no public or territorial law that make it necessary for organizations to embrace and carry out IFRS in Ethiopia (Pasricha \& Teferi, 2016). During this period the selection of IFRS in Ethiopia has been a drowsy cycle. 
Be that as it may, after the endorsement of the House of Representatives, the Ethiopian Financial Reporting Proclamation was given with Proclamation No. 847/2014 in the Federal Negarit Gazette of the Federal Democratic Republic of Ethiopia dated Dec 5, 2014, efforts have been put to improve the Ethiopian Financial detailing climate with regards to IFRS appropriation (Yitayew, 2016). The authorization of a proclamation to provide for financial reporting (Proclamation No. 847/2014) is the current improvement in the accounting, auditing and financial announcing history in Ethiopia (Ethiopian Government, 2014).

One thing that is clear is the implementation of IFRS is certainly not a simple assignment because of the way that few that difficulties that could be looked in the method of its execution. These difficulties become much aggravate in developing nations. Non-industrial nations are defied by extra difficulties and hindrances in embracing and executing IFRS (Zeghal \& Mhedhbi, 2006; Elias, 2012; Houqe \& Monem, 2016). Tawiah (2019) IFRS appropriation in Africa is delayed because of absence of institutional and expert limit. This isn't extraordinary to Ethiopia.

As one of the quickest financial development country in sub-Saharan Africa, Ethiopia addresses a potential climate with regards to which to research the appropriateness of IFRS in developing nations uniquely in financial sector. In line with this, the essential target of this paper is to evaluate whether financial data under IFRS is appropriate for clients' requirements in financial sector especially for banking sector. This examination adds to and broadens the surviving writing, which has chiefly centered around evolved economies, by giving exact proof of the appropriateness of IFRS in financial sector from the viewpoint of inner clients (the executives) and outer gatherings (for example scholastics and external auditors).

\section{RESEARCH METHODOLOGY}

\section{Sampling}

The polls provided for the scholastics, external auditors and banks financial directors to acquire the essential information to discover observational proof of the reasonableness of IFRS for banking sector in Ethiopia. The investigation is insightful overview, which means it is intended to clarify the reasonableness of IFRS as opposed to depict a population. Subsequently, representativeness of 
the example to the population was not the objective of the investigation; the endeavor rather has been made to guarantee legitimacy of the information by applying purposive inspecting (Oppenheim, 1992). This methodology is designed to catch the assessments of scholastics, external auditors and banks financial directors. To this end, the examination caught those scholastics, external auditors and banks' financial directors who have rich information and involvement with IFRS execution in financial sector in Ethiopia.

The overview focused on three classes of respondents. The principal classification involved the Financial supervisors/Directors 10 commercial banks in Ethiopia. Presently it arrived at 18, of which 16 are private and 2 are statepossessed in 2017/18. More than $70 \%$ of the commercial banks from the overall industry are controlled by the government owned bank the Ethiopian Commercial Bank (Mesele, 2019). The Financial head of the Commercial Banks in Ethiopia was the target of this overview considering the enormous offer the bank has in the market and its suggestion for this investigation. What's more, the respondents in this classification stand firm on critical footings liable for dealing with the organization's financial matters and settling on expansive asset designation choices.

As the second and third classes of respondents, the views of scholastics in Accounting and Auditing were acquired. These example targets were picked to acquire bits of knowledge into the investigation subject from the two experts and scholastics. The example size of 30 polls was sent through email utilizing on the web overview. Among the three classifications: 10 surveys to banks Financial directors covering the 10 principal Commercial banks in Ethiopia; 10 polls to scholastics, including Accounting employees from Addis Ababa University, Addis Ababa college business school , Civil Service University ; and 10 surveys to External auditors (Seniors) covering the BDO - Ethiopia, Grant Thornton Ethiopia , PricewaterhouseCoopers (PWC), and HST-Ethiopia. These three gatherings were picked on the grounds that they are the principle clients of IFRS and were accepted to have the most experience and adequate information concerning IFRS (Russell, 2015; Mardini, Crawford \& Power, 2015; Tahat et al., 2016). The reaction rate was roughly $83 \%$ (26 members) among all classes. A few members didn't react by any means, while different overviews were not completely finished. Consequently, the last example was 10 financial supervisors, 9 scholastics in Accounting and 7 external auditors; the External auditors were eventually credited 10 overviews to keep away from any superfluous 
huge contrasts across the three classes. The last example measure is summed up in table.

The survey comprised of three sectors: the primary segment looked for segment data about the example respondents, the subsequent segment comprised of 12 inquiries with respect to the upsides of IFRS appropriation by Ethiopian Banks and the third segment comprised of 7 inquiries in regards to the obstructions and impediments of IFRS selection. Each question on the benefits or weaknesses brought about an end. For example, if the respondent couldn't help contradicting a benefit explanation, the benefit was viewed as a hindrance from the example respondent's viewpoint and the other way around. A five-point Likert scale was utilized in which 5 addressed "unequivocally concur" and 1 designated "firmly oppose this idea." To acquire further remarks from the respondents, space was accommodated to discretionary remarks on the subject. The analysts led a pilot investigation of three financial directors, three scholastics and three external auditors to pre-test whether the study instrument was clear and gotten the data looked for and to upgrade the poll's design and legitimacy. The outcomes were dissected by distinct measurements, ANOVA tests, connection investigation (Pearson) and the Kruskal-Wallis test.

\section{RESULTS AND DISCUSSION}

\section{Demographic analysis of participants}

The main objective of the study was to assess the suitability of IFRS for banking sector in sub-Saharan African countries such as Ethiopia. This research explores the advantages and disadvantages of IFRS implementation in banking sector in Ethiopia based on the perceptions of Banks financial directors, academics in accounting and external auditors about the suitability of IFRS in banking sector in Ethiopia. 
Table 1. Final sample process: Notes: FM, financial managers; $\mathrm{AA}$, academics in accounting; EA, external auditors

\begin{tabular}{|l|c|c|c|}
\hline \hline \multicolumn{1}{|c|}{ Sampling/categories } & FM & AA & EA \\
\hline \hline Initial sample & 10 & 10 & 10 \\
\hline Responses & 10 & 9 & 70 \\
\hline Response rate (\%) & 100 & 90 & 3 \\
\hline Incomplete responses & - & 1 & - \\
\hline Avoid statistical differences & - & - & 7 \\
\hline Final sample & 10 & 9 & \\
\hline \hline
\end{tabular}

S o u r c e : author's construction.

These insights were gotten through online poll review with 10 members for every gathering. The current subsection sums up the segment data of the members utilizing certain expressive measurements to give bits of knowledge into the members' experiences. As demonstrated in table 2, banks financial directors, scholastics and External auditors partook as respondents. Every one of the respondents of banks were financial directors. Table 2 sums up the position (title) of the accounting scholastics who took an interest in the examination. The scholarly respondents were employees of Ababa Addis University, Addis Ababa University School of Commerce and Ethiopian Civil Service University. A dominant part of the scholarly respondents were senior speakers (66. percent), trailed by Assistance Professors (22.2 percent) and talks (10.0 percent). The work titles of the members in the third gathering (External auditors) were group pioneers, which included BDO - Ethiopia, Grant Thornton Ethiopia, PricewaterhouseCoopers (PWC), and HST-Ethiopia evaluators. Table 3 shows that a majority of respondents (banks were Financial directors) were 25-35 years of age and 35-45 years of age (30 and 60 percent individually), while a minority were more established than 45 years ( 10 percent). Table 3 shows the long periods of involvement for the respondents across the three gatherings. The biggest gathering of respondents had 11 to 20 years of involvement (on normal $62 \%$ ), trailed by over 20 years (on normal 29.7 .3\%). The poll review likewise incorporated certain segment data, for example, the gender orientation which could be discovered in the study. 
Empirical evidence of the suitability of IFRS...

Table 2. Industry membership, the academic title and job title of respondents

\begin{tabular}{|c|l|c|c|}
\hline \hline & \multicolumn{1}{|c|}{ Job title } & No. & $\%$ \\
\hline \hline FM & Finance director & 10 & $100.0 \%$ \\
\hline & Total & 10 & $100.0 \%$ \\
\hline AA & Assistant professor & 2 & $22.2 \%$ \\
\hline & Lecturer & 1 & $11.1 \%$ \\
\hline & Senior lecturer & 6 & $66.7 \%$ \\
\hline EA & Total & 9 & $100.0 \%$ \\
\hline & Team leader & 7 & $100.0 \%$ \\
\hline \hline
\end{tabular}

S o u r c e : author's construction.

Table 3. Age and years of experience of respondents

\begin{tabular}{|c|c|c|c|c|c|c|}
\hline & FM & & AA & & EA & \\
\hline Age & No. & $\%$ & No. & $\%$ & No. & $\%$ \\
\hline $20-25$ & & & & & 1 & $14.3 \%$ \\
\hline $25-30$ & 1 & $10.0 \%$ & & & & \\
\hline $30-35$ & 2 & $20.0 \%$ & 1 & $11.1 \%$ & 1 & $14.3 \%$ \\
\hline $35-40$ & 4 & $40.0 \%$ & 4 & $44.4 \%$ & & \\
\hline $40-45$ & 2 & $20.0 \%$ & 3 & $33.3 \%$ & 4 & $57.1 \%$ \\
\hline Above 45 & 1 & $10.0 \%$ & 1 & $11.1 \%$ & 1 & $14.3 \%$ \\
\hline Total & 10 & $100.0 \%$ & 9 & $100.0 \%$ & 7 & $100.0 \%$ \\
\hline Years of experience & $\mathrm{FM}$ & & $\mathrm{AA}$ & & EA & \\
\hline Experience (in years): & No. & $\%$ & No. & $\%$ & No. & $\%$ \\
\hline $5-10$ & 1 & $10.0 \%$ & & & 1 & $14.3 \%$ \\
\hline $11-20$ & 8 & $80.0 \%$ & 7 & $77.8 \%$ & 2 & $28.6 \%$ \\
\hline Above 20 & 1 & $10.0 \%$ & 2 & $22.2 \%$ & 4 & $57.1 \%$ \\
\hline Total & 10 & $100.0 \%$ & 9 & $100.0 \%$ & 7 & $100.0 \%$ \\
\hline
\end{tabular}

S o u r c e : author's construction. 
The demographic information and its analysis are useful to this study on many levels. First, the information signals that the respondents were capable to answer the questionnaire in a professional manner. Specifically, a majority of the respondents were well experienced in their field, were young and varied in terms of background. Second, the banks financial manager respondents covered the majority of commercial banks in Ethiopia; the academics in accounting represented all academic rankings, and the external auditor participants represented all of the big auditing firms in Ethiopia including the Big four.

\section{IFRS SUITABILITY}

This subsection examines about the proof of IFRS appropriateness for banking sector in Ethiopia depending on the view of banks financial directors, scholastics in the Accounting field and external auditors. Table 4 represents the members' perspectives on the upsides of IFRS for banking sector in Ethiopian business climate. The greater part of the respondents concurred that the selection of IFRS is helpful for banking sector from various perspectives. In particular, most members across the three gatherings concurred that IFRS is useful to expand Banks investors' trust in Financial revealing (mean of 4.444 and 4.714, individually). Also, the respondents considered IFRS a supportive arrangement of norms that creates and upgrades the certainty of new financial backers to purchase the bank's offers as consequence of the Financial announcing (4.571), improves coordinate administration (mean of 4.571), improves the nature of Financial revealing and divulgences (mean of 4.857), tackles the issues of readiness of Financial detailing in Banks for upgrade (mean of 4.143), builds the degree of Financial announcing and disclosures(mean of 5) and expands the importance of Financial answering to clients of budget reports (4.571).

Nonetheless, as per the Kruskal-Wallis test, the reactions to certain assertions varied altogether among the three gatherings at a p estimation of $>0.01$, like explanations 1 and 5 (tables 5). Nonetheless, the reactions to different articulations varied at an important level of under $10 \%$ or $5 \%$. All gatherings showed the union to upgrade corporate Financial execution and position and improve the nature of Financial announcing and revelations (methods for 4.92 and 4.85, individually), proposing that IFRS gigantically affects the improvement of corporate Financial execution and position and improves the nature of Financial revealing and divulgences in financial sector in Ethiopia. 
Empirical evidence of the suitability of IFRS...

Table 4. Descriptive statistics of advantages of IFRS

\begin{tabular}{|c|c|c|c|c|c|}
\hline & FM & AA & EA & Total & Sign. \\
\hline \multirow{2}{*}{$\begin{array}{l}\text { 1.Increases Banks shareholders' confidence in } \\
\text { financial reporting }\end{array}$} & 4.3 & 4.444 & 4.714 & 4.5 & \\
\hline & 0.483 & 0.527 & 0.488 & 0.499 & \\
\hline \multirow{2}{*}{$\begin{array}{l}\text { 2.Increases the confidence of new investors } \\
\text { to buy the bank's shares as the result of the } \\
\text { financial reporting }\end{array}$} & 4.4 & 4 & 4.571 & 4.3 & \\
\hline & 0.516 & 0.707 & 0.787 & 1.005 & \\
\hline \multirow[t]{2}{*}{ 3. Leads to more deposit flow into the bank } & 3.1 & 3.444 & 3.714 & 3.4 & \\
\hline & 0.876 & 0.527 & 0.756 & 0.72 & \\
\hline \multirow[t]{2}{*}{ 4.Increases the QE efficiency } & 3.444 & 4 & 3.857 & 3.8 & \\
\hline & 0.726 & 0.756 & 0.69 & 0.724 & \\
\hline \multirow[t]{2}{*}{ 5.Enhances cooperate governance } & 4.7 & 4.444 & 4.571 & 4.6 & \\
\hline & 0.483 & 0.527 & 0.535 & 0.773 & \\
\hline \multirow{2}{*}{$\begin{array}{l}\text { 6. Enhances the implementation of Ethiopian } \\
\text { National Bank rules and regulations }\end{array}$} & 3.2 & 3.333 & 3.857 & 3.5 & \\
\hline & 1.135 & 1.118 & 1.069 & 1.107 & \\
\hline \multirow{2}{*}{$\begin{array}{l}\text { 7.Solve the problems of preparation of finan- } \\
\text { cial reporting in Banks }\end{array}$} & 3.8 & 4 & 4.143 & 3.98 & \\
\hline & 0.919 & 0.5 & 0.9 & 0.773 & \\
\hline \multirow{2}{*}{$\begin{array}{l}\text { 8. Increases the level of financial reporting and } \\
\text { disclosures }\end{array}$} & 5 & 4.778 & 5 & 4.92 & \\
\hline & 0 & 0.441 & 0 & 0.441 & \\
\hline \multirow{2}{*}{$\begin{array}{l}\text { 9.Improves the quality of financial reporting } \\
\text { and disclosures }\end{array}$} & 4.9 & 4.778 & 4.857 & 4.85 & \\
\hline & 0.316 & 0.441 & 0.378 & 0.378 & \\
\hline \multirow{2}{*}{$\begin{array}{l}\text { 10.Enhances corporate financial performance } \\
\text { and position }\end{array}$} & 3.9 & 3.778 & 4.714 & 4.13 & * \\
\hline & 1.101 & 0.833 & 0.488 & 0.807 & \\
\hline \multirow{2}{*}{$\begin{array}{l}\text { 11. Reduces preparation cost of financial } \\
\text { reporting }\end{array}$} & 1.5 & 2.333 & 2.429 & 2.09 & $* *$ \\
\hline & 0.527 & 1 & 0.976 & 0.834 & \\
\hline $\begin{array}{l}\text { 12.Increases the relevance of financial repor- } \\
\text { ting to users of financial statements }\end{array}$ & 4.7 & 4.556 & 4.571 & 4.61 & \\
\hline
\end{tabular}


Table 4. Descriptive...

\begin{tabular}{|c|c|c|c|c|}
\hline FM & AA & EA & Total & Sign. \\
\hline 0.483 & 1.014 & 0.535 & 0.677 & \\
\hline $\begin{array}{l}\text { Sign. }=\text { statistical difference among the three groups (*at } \\
\left.10 \%,{ }^{* *} \text { at } 5 \% \text { and }{ }^{* * *} \text { at } 1 \%\right) \text { using the Kruskal-Wallis test }\end{array}$ & & & & \\
\hline $\begin{array}{l}\text { The } x 2 \text { test shows that the proportions in each category are } \\
\text { not different across the groups }(x 2=1.209, p \text {-value }<0.10)\end{array}$ & & & & \\
\hline
\end{tabular}

S o u r c e : author's construction.

Table 5. Descriptive statistics of disadvantages of IFRS

\begin{tabular}{|c|c|c|c|c|c|}
\hline & FM & AA & EA & Total & Sign. \\
\hline \multirow{2}{*}{$\begin{array}{l}\text { 1. The convergence to IFRS may lead to a contra- } \\
\text { diction with Ethiopian banking laws and corpo- } \\
\text { rate responsibility }\end{array}$} & 4 & 2.556 & 2.571 & 3.04 & $* * *$ \\
\hline & 0.816 & 0.882 & 1.272 & 0.99 & \\
\hline \multirow{2}{*}{$\begin{array}{l}\text { 2. The financial information prepared under } \\
\text { IFRS may lead to misunderstanding by users of } \\
\text { financial statements }\end{array}$} & 3.4 & 2.444 & 2.286 & 2.71 & $*$ \\
\hline & 1.174 & 1.236 & 0.951 & 1.12 & \\
\hline \multirow{2}{*}{$\begin{array}{l}\text { 3. IFRS are complicated and difficult to under- } \\
\text { stand }\end{array}$} & 3.3 & 2.667 & 2.571 & 2.85 & \\
\hline & 1.16 & 0.866 & 1.512 & 1.179 & \\
\hline \multirow{2}{*}{$\begin{array}{l}\text { 4. A lack of adequate knowledge and experience } \\
\text { may lead to IFRS being used wrongly }\end{array}$} & 4.3 & 3.778 & 4.286 & 4.12 & \\
\hline & 0.675 & 0.972 & 0.951 & 0.866 & \\
\hline \multirow{2}{*}{$\begin{array}{l}\text { 5. Academic institutes have not paid attention } \\
\text { to IFRS in their accounting programmes }\end{array}$} & 4.6 & 2.667 & 4.429 & 3.9 & $* * *$ \\
\hline & 0.516 & 1.414 & 0.976 & 0.969 & \\
\hline \multirow{2}{*}{$\begin{array}{l}\text { 6. The Ethiopian business environment and } \\
\text { banking system is not ready for convergence } \\
\text { with IFRS }\end{array}$} & 2.6 & 2.333 & 2.714 & 2.55 & \\
\hline & 0.516 & 0.866 & 1.704 & 1.03 & \\
\hline \multirow[t]{2}{*}{ 7. The implementation of IFRS is very costly } & 4.5 & 3.444 & 3.286 & 3.74 & \\
\hline & 0.85 & 0.726 & 1.704 & 1.093 & $* *$ \\
\hline
\end{tabular}


Table 5. Descriptive...

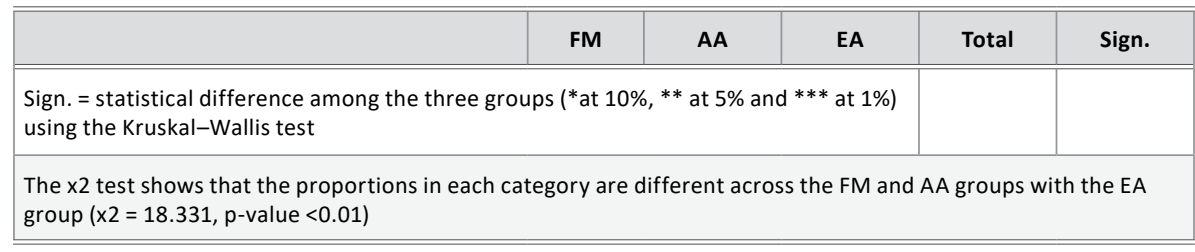

S o u r c e : author's construction.

Then again, most members demonstrated that IFRS didn't diminish the readiness expenses of fiscal summaries (mean of 2.09); rather they found the execution of IFRS by one way or another exorbitant (mean of 3.74, table 5). This finding recommends that the execution and reception of IFRS was exorbitant for Ethiopian financial sector. This finding negated with the IFRS advocates contention that IFRS decreases data expenses to an economy, especially as capital streams and exchange become more globalized (Leuz, 2003; Barth, 2008). Regarding the subjective qualities of financial detailing, the members accepted that IFRS gives more pertinent and devoted portrayals of fiscal reports to clients.

Table 5 shows the respondents' view of the weaknesses of IFRS for the Ethiopian financial sector. Obviously the respondents considered the execution of IFRS in Ethiopian financial sector to be in some way or another tricky. For example the dominant part of the respondents tracked down that an absence of satisfactory information and experience may prompt IFRS to be utilized wrongly in financial sector in Ethiopia (mean of 4.12). Anyway most of the respondents tracked down that the assembly to IFRS may not prompt a logical inconsistency with Ethiopian financial laws and corporate obligation (mean of 3.04). Also, most of the respondents demonstrated that Financial detailing under IFRS didn't prompt misconception by the clients of budget reports (mean of 2.71) and that IFRS was not hard to comprehend (mean of 2.85). These outcomes recommend that the financial data detailed under IFRS is justifiable. IFRS gives a globalized set of accounting standards that urge the banking sector to give dependable and solid financial data. Albeit the respondents considered IFRS reasonable, they noticed that information and experience are needed to stay away from inaccurate utilization of budget summaries (mean of 4.12). Consequently, in spite of the fact that IFRS is reasonable, important, and steadfastly addressing budget reports, the execution and materialness of 
IFRS expect information to guarantee that these advantages are given to the business climate all around the world, sub-Saharan Africa and to the Ethiopian financial business climate specifically. Scholastic foundations in Ethiopia need to give adequate IFRS information to their understudies and the Ethiopian people group. Most of members in this examination disagreed that scholastic foundations have focused on IFRS in their Accounting projects to deliver qualified and able labor with respect to IFRS to Ethiopian work market (mean of 3.9). So they have zeroed in on IFRS in their projects, which have apparently given leaders and clients of budget reports with satisfactory information to comprehend IFRS.

To look at the most powerful benefits/inconveniences of IFRS reasonableness across the three gatherings, an ANOVA test was performed for every assertion. The outcomes are summed up in table 6. Explanations 1, 2, 5, 8, 9, 10 and 12 (of the benefits proclamations) varied fundamentally among the three gatherings. Alternately, just articulations 4, 5 and 7 (of the hindrances explanations) varied essentially among the three gatherings. For instance, all concurred that participate administration, level of Financial announcing, nature of Financial detailing and revelations and significance of Financial answering to clients of fiscal reports exposures were the main determinants of the reasonableness of embracing IFRS in sub-Saharan Africa nations banking sector by and large and Ethiopia specifically. Supporting the consequences of the ANOVA examination, the Kruskal-Wallis test uncovered that the impression of the three gatherings varied fundamentally for benefits proclamations 1, 2, 5, 8, 9, 10 and 12 and weaknesses articulation 4 (tables 4 and 5).

Table 6. Anova A test of statement analysis across the three groups

\begin{tabular}{|c|l|c|c|c|c|}
\hline \hline & \multicolumn{5}{|c|}{6.1 SUMMARY: Advantages } \\
\hline \hline 1. & $\begin{array}{l}\text { Increases Banks shareholders' confi- } \\
\text { dence in financial reporting }\end{array}$ & 26 & 116 & 4.46153846 & 0.25846154 \\
\hline 2. & $\begin{array}{l}\text { Increases the confident of new inve- } \\
\text { stors to buy the bank's shares as the } \\
\text { result of the financial reporting }\end{array}$ & 26 & 112 & 4.30769231 & 0.46153846 \\
\hline 3. & $\begin{array}{l}\text { Leads to more deposit flow into the } \\
\text { bank }\end{array}$ & 26 & 88 & 3.38461538 & 0.56615385 \\
\hline 4. & Increases the QE efficiency & 24 & 90 & 3.75 & 0.54347826 \\
\hline
\end{tabular}


Empirical evidence of the suitability of IFRS...

Table 6. Anova...

\begin{tabular}{|c|c|c|c|c|c|c|c|c|}
\hline & \multicolumn{8}{|c|}{ 6.1 SUMMARY: Advantages } \\
\hline & & & Count & Sum & \multicolumn{2}{|c|}{ Average } & \multicolumn{2}{|r|}{ Variance } \\
\hline 5. & \multicolumn{2}{|c|}{ Enhances cooperate governance } & 26 & 119 & \multicolumn{2}{|c|}{4.57692308} & \multicolumn{2}{|c|}{0.25384615} \\
\hline 6. & \multicolumn{2}{|c|}{$\begin{array}{l}\text { Enhances the implementation of } \\
\text { Ethiopian National Bank rules and } \\
\text { regulations }\end{array}$} & $2 \epsilon$ & 89 & \multicolumn{2}{|c|}{3.42307692} & \multicolumn{2}{|c|}{1.21384615} \\
\hline 7. & \multicolumn{2}{|c|}{$\begin{array}{l}\text { Solve the problems of preparation of } \\
\text { financial reporting in Banks }\end{array}$} & 26 & 103 & \multicolumn{2}{|c|}{3.96153846} & \multicolumn{2}{|c|}{0.59846154} \\
\hline 8. & \multicolumn{2}{|c|}{$\begin{array}{l}\text { Increases the level of financial repor- } \\
\text { ting and disclosures }\end{array}$} & 26 & 128 & \multicolumn{2}{|c|}{4.92307692} & \multicolumn{2}{|c|}{0.07384615} \\
\hline 9. & \multicolumn{2}{|c|}{$\begin{array}{l}\text { Improves the quality of financial } \\
\text { reporting and disclosures }\end{array}$} & 26 & 126 & \multicolumn{2}{|c|}{4.84615385} & \multicolumn{2}{|c|}{0.13538462} \\
\hline 10. & \multicolumn{2}{|c|}{$\begin{array}{l}\text { Enhances corporate financial perfor- } \\
\text { mance and position }\end{array}$} & 26 & 106 & \multicolumn{2}{|c|}{4.07692308} & \multicolumn{2}{|c|}{0.87384615} \\
\hline 11. & \multicolumn{2}{|c|}{$\begin{array}{l}\text { Reduces preparation cost of financial } \\
\text { reporting }\end{array}$} & 26 & 53 & 2.0384 & 5154 & & .83846154 \\
\hline 12. & $\begin{array}{l}\text { Increases the releva } \\
\text { reporting to users of } \\
\text { tements }\end{array}$ & $\begin{array}{l}\text { inancial sta- } \\
\text { inancial }\end{array}$ & 26 & 120 & 4.6153 & 3462 & & .48615385 \\
\hline & ANOVA: Advantage & & & & & & & \\
\hline & Source of Variation & SS & $d f$ & MS & $\boldsymbol{F}$ & $P$-ve & & F crit \\
\hline & Between Groups & 187.177419 & 11 & 17.016129 & 32.4013192 & 1.036 & & 1.59232479 \\
\hline & Within Groups & 156.5 & 298 & 0.52516779 & & & & \\
\hline & Total & 343.677419 & 309 & & & & & \\
\hline
\end{tabular}

S o u r c e : author's construction.

\begin{tabular}{|c|l|c|c|c|c|}
\hline \hline \multicolumn{7}{|c|}{6.2 SUMMARY: Disadvantages } \\
\hline \hline Groups & Count & Sum & Average & Variance \\
\hline \hline 1. & $\begin{array}{l}\text { The convergence to IFRS may lead to } \\
\text { a contradiction with Ethiopian ban- } \\
\text { king laws and corporate responsibility }\end{array}$ & 26 & 81 & 3.11538462 & 1.38615385 \\
\hline 2. & $\begin{array}{l}\text { The financial information prepared } \\
\text { under IFRS may lead to misundersto- } \\
\text { od by users of financial statements }\end{array}$ & 26 & 72 & 2.76923077 & 1.46461538 \\
\hline 3. & $\begin{array}{l}\text { IFRS are complicated and difficult to } \\
\text { understand }\end{array}$ & 26 & 75 & 2.88461538 & 1.38615385 \\
\hline
\end{tabular}


Table 6. Anova...

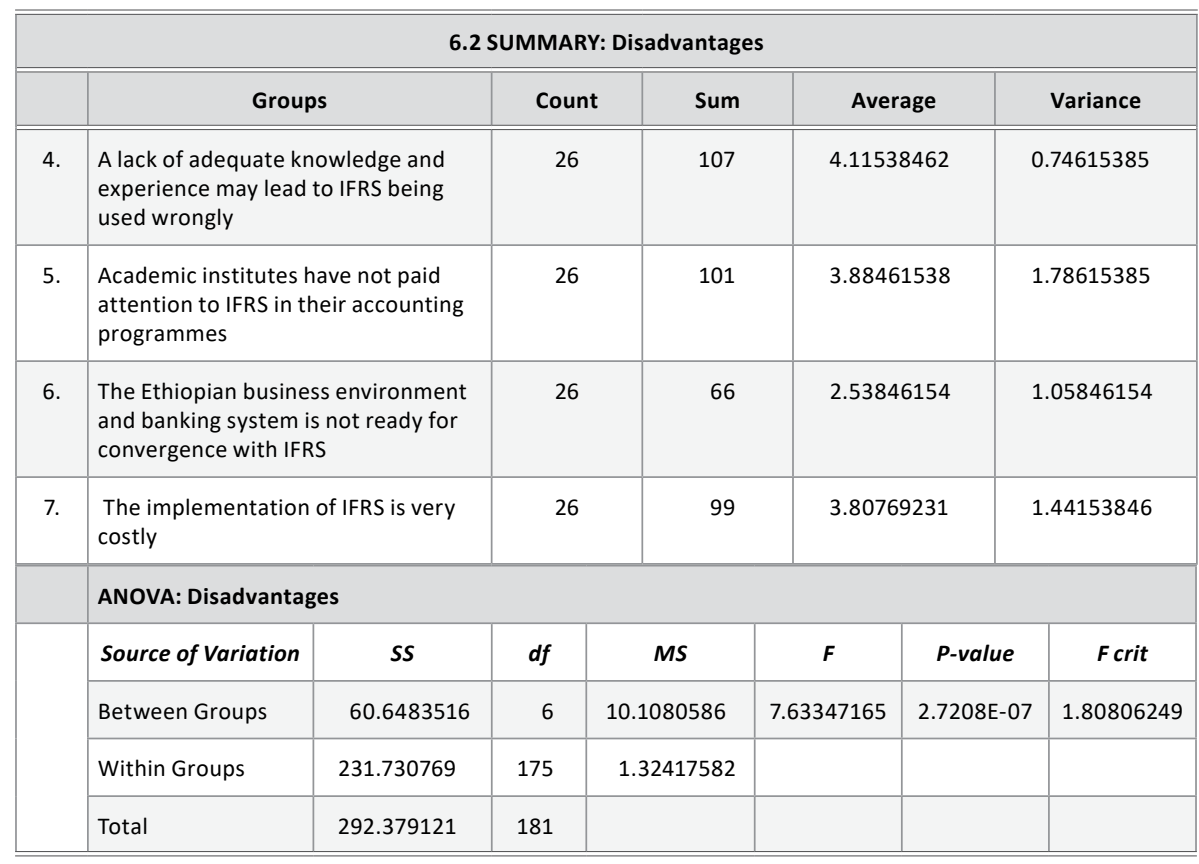

S o u r c e : author's construction.

The distinctions among the examination bunches in their conclusions about a portion of the exploration articulations, especially the benefits of IFRS, may mirror the work idea of each gathering and its connection to the use of IFRS. External auditors are in contact with banks; financial supervisors are the gathering answerable for IFRS application and just address the framework in their organization. Scholastics are not by and by and counsel as opposed to execute. The last assertion of the overview was an open-finished inquiry posing to the respondents to alternatively give extra remarks about IFRS appropriateness. The members in the external auditors bunch added no remarks, for example this inquiry stayed clear. In any case, various Accounting scholastics and banks financial directors added extraordinary bits of knowledge. One bank Financial director contended that "Despite the fact that cost of change is high interestingly, if Universities are prepared towards IFRS and graduates have both specialized and hypothetical information, it will be all the more simple," An educator in Accounting added a remark about the administrative body IFRS in Ethiopia, 
expressing that "Ethiopian Accounting and Auditing Board (AABE) has limit issue and isn't satisfactorily set up to guide and direct the execution of IFRS. Moreover, there is absence of mindfulness on the execution interaction." These remarks recommend that to carry out IFRS adequately in various businesses in Ethiopia especially in Ethiopian banks, it needs joined endeavors to improve more reasonable eco framework in Ethiopia just as the sector. These remarks are steady with the measurable aftereffects of this investigation: execution and relevance of IFRS expect information to get a large portion of its advantages in the business climate all around the world and in the Ethiopia banking business climate specifically. Hence, the open ended answers affirmed the discoveries from the shut finished answers.

\section{ConCLUSIONS}

This careful investigation upholds the appropriateness of IFRS for banking sector in Ethiopia. IFRS gives benefits to the financial sector in Ethiopia, standards regardless of whether it makes banks causing extra significant expenses in the reception cycle. Also, this investigation proposes that IFRS combination places without logical inconsistency with Ethiopian financial laws and corporate duty. In addition, in light of the respondents' perspectives, IFRS is reasonable to clients and pertinently and loyally addresses the fiscal reports of Ethiopian Banks; notwithstanding, the execution and materialness of IFRS expect information to acquire the greater part of its advantages and benefits. The respondents showed that scholastic establishments have not focused on IFRS in their Accounting programs and not given this information to the clients of the budget reports in Ethiopia. By and large, IFRS has all the earmarks of being appropriate for sub-Saharan financial sector all in all and Ethiopian financial sector specifically. This investigation has critical ramifications for accounting controllers in Ethiopia and for banking sector specifically by giving experiences into the appropriateness of IFRS and its effect on degree of financial revealing and exposures, nature of financial detailing and revelations and corporate administration.

Moreover, the aftereffects of this paper can help different controllers in the district create Accounting standards that adjust their laws to the significant elements influencing the reasonableness of IFRS. Certain constraints of the current investigation should be recognized. In the first place, the Ethiopian finan- 
cial sector association culture factor was not tended to in this investigation. Second, this exploration utilized a poll overview to analyze the appropriateness of IFRS for banking sector in Ethiopia, and there is a danger that a portion of the assertions were not perceived enough by the respondents. Be that as it may, such mistaken assumptions were limited by giving clear and succinct explanations and, when fundamental, explaining the study to certain respondents via telephone.

\section{REFERENCES}

Africa Development Bank (ADB) (2020). African Economic Outlook 2020, https://www. afdb.org/en/knowledge/publications/african-economic-outlook.

Barth, M.E. (2008). Global financial reporting: Implications for US. The Accounting Review, 83(5), 1159-1179.

Benjamin, J.J., \& Stanga, K.G. (1977). Differences in disclosure needs of major users of major financial statements. Accounting and Business Research, 7(27), 187-192. http://dx.doi.org/10.1080/00014788.1977.9728702.

Callao, S., Jarne, J.I., \& Laínez, J.A. (2007), Adoption of IFRS in Spain: effect on the comparability and relevance of financial reporting. Journal of International Accounting, Auditing and Taxation, 16(2), 148-178.

Christian, C., \& Kohlmeyer, J.M., III. (2009). U.S. adoption of international accounting standards: Why now? Commercial Lending Review, 8-13.

Elias, N. (2012). Discussion of the impact of mandatory IFRS adoption on accounting quality: evidence from Australia. Journal of International Accounting Research, 11(1), 147-154.

Ethiopian Government (2014). A proclamation to provide for Financial Reporting, Proclamation No. 847/2014. Federal Negarit Gazette, 20th Year, No. 81, Addis Ababa, December, 7714.

Gordon, E.A. (2008). Sustainability in Global Financial Reporting and Innovation in Institutions. Accounting Research Journal, 21(3), 231-238. http://doi. org/10.1108/10309610810922486.

Houqe, M., \& Monem, R. (2016). IFRS adoption, extent of disclosure, and perceived corruption: a Cross-Country study. The International Journal of Accounting, 51(3), 363-378. http://dx.doi.org/10.1016/j.intacc.2016.07.002.

International Accounting Standards Board (IASB) (2010). Conceptual Framework for Financial Reporting (the IFRS Framework). London: International Accounting Standards Board.

International Accounting Standards Committee (IASC) (1989). The IASC Framework: Framework for the Preparation and Presentation of Financial Statements. London: International Accounting Standards Committee. 
Jermakowicz, E.K., \& Gornik-Tomaszewski, S. (2006). Implementing IFRS from the perspective of EU publicly traded companies. Journal of International Accounting, Auditing and Taxation, 15(2), 170-196. http://dx.doi.org/10.1016/j.intaccaudtax.2006.08.003.

Leuz, C. (2003). IAS versus US GAAP: information asymmetry-based evidence from Germany's new market. Journal of Accounting Research, 41(3), 445-472.

Mardini, G., Crawford, L., \& Power, D. (2015). Perceptions of external auditors, preparers and users of financial statements about the adoption of IFRS 8. Journal of Applied Accounting Research, 16(1), 2-27. http://dx.doi.org/ 10.1108/JAAR-09-2012-0066.

Mardini, G.H., \& Tahat, Y. (2017). An empirical evidence on audit selection and audit rotation: the case of Qatari listed companies. International Journal of Accounting, Auditing and Performance Evaluation, 13(1), 99-122. http://dx.doi.org/10.22495/rcgv6i3c1art2.

Mesele, M. (2019). Financial Sector Development and Economic Growth in Ethiopia: Literature Review. Journal of Finance and Accounting, 10(5), 1-11. http://dx.doi. org/10.7176/RJFA/10-5-01.

Mohammadi, A., \& Mardini, G.H. (2016). Financial instruments disclosure: the case of Qatari listed banks. Afro-Asian J. Of Finance and Accounting, 6(2), 160-182.

Oppenheim, A.N. (1992). Questionnaire, design, interviewing and attitude measurement. London: Pinter Pub Ltd.

Pasricha, J.S., \& Teferi, D.A. (2016). IFRS Adoption Progress in Ethiopia. Research Journal of Finance and Accounting, 7(1), 55-65.

Rahman, A., Lei, C., \& Courtenay, S. (2014). The effect of IFRS adoption conditional upon the level of pre-adoption divergence. The International Journal of Accounting, 49(2), 183-189.

Russell, M. (2015). Continuous disclosure and information asymmetry. Accounting Research Journal, 28(2), 195-224.

Tahat, Y., Dunne, T., Fifield, S., \& Power, D. (2016). The impact of IFRS 7on the significance of financial instruments disclosure: evidence from Jordan. Accounting Research Journal, 29(3), 241-273.

Tawiah, V. (2019). The State of IFRS in Africa. Journal of Financial Reporting and Accounting, 17(4), 635-649. http://dx.doi.org/10.1108/JFRA-08-2018-0067.

Yitayew, M. (2016). IFRS Adoption in Ethiopia: A Critical Analysis of the Process, Issues and Implications. A Thesis Submitted to the School of Graduate Studies of Addis Ababa University in Partial Fulfillment of the Requirements for the Degree of Master of Science in Accounting and Finance.

Zeghal, D., \& Mhedhbi, K. (2006), An analysis of the factors affecting the adoption of international accounting standards by developing countries. The International Journal of Accounting, 41(4), 373-386. 